\title{
The Modigliani-Miller Theorem with Financial Intermediation
}

\author{
John F. McDonald \\ Walter E. Heller College of Business Administration, Roosevelt University, Chicago, USA \\ E-mail: jmcdonald@roosevelt.edu \\ Received January 27, 2011; revised March 6, 2011; accepted April 3, 2011
}

\begin{abstract}
This paper shows that, if firms borrow at an interest rate that is greater than the rate at which they can lend, the value of a firm declines with the amount borrowed. The model assumes the possibility that a firm may go bankrupt, which introduces the need for financial intermediation. A modified version of the homemade leverage examples introduced by Modigliani and Miller [1] is used to introduce the concept. A state-preference model is used for a more formal proof.
\end{abstract}

Keywords: Modigliani-Miller Theorem, Financial Intermediation, Valuation

\section{Introduction}

The purpose of this paper is to investigate the effect of borrowing on the value of firms (and other financial investments). Even investment entities such as real estate investment trusts that are not subject to income taxation at the entity level borrow. For example, Chan, Erickson, and Wang [1] found that $187 \mathrm{U}$. S. real estate investment trusts in 2000 borrowed an average of 50\% measured as long-term debt to total capital and $46 \%$ measured as long-term debt to total market capitalization. These are entities for which there is no tax advantage in borrowing. According to the classic Modigliani-Miller theorem [2], borrowing by these untaxed entities has no effect on market value. However, this conclusion depends upon the assumption that the interest rate at which the real estate investing entity can borrow equals the rate at which the entity can lend. Alteration of this assumption produces a different conclusion; if the borrowing rate is greater than the lending rate, then the value that the real estate investing entity places upon a particular property will decline with the amount borrowed.

The original article by Modigliani and Miller [2] very recently was named by Arrow, et al. [3] one of the top twenty articles that appeared in the first one hundred years of the American Economic Review. The citation for this award [2] reads in part.

The paper's central result is that, in a setting with complete capital markets and in the absence of tax-induced distortions, a firm's total market value is invariant to its borrowing behavior. This powerful result can be demonstrated constructively, by developing a straightforward set of borrowing or lending transactions that an equity investor can undertake to offset the consequences of changes in corporate borrowing. The analytical approach in this paper is one of the key foundations for the modern field of financial economics.

The purpose of this paper is to add the service of financial intermediation to the Modigliani-Miller model.

It is now widely recognized that the supply of financial intermediation services is an important element to include in financial models. Woodford [4] has developed a macroeconomic model that includes financial intermediation in order to explain important aspects of the most recent financial crisis and recession. The basic idea is that there exists a loan production function that requires the use of real resources, and that the volume of lending by intermediaries involves diminishing returns to increases in variable inputs (rising marginal costs) because of fixity of some inputs such as specialized expertise. Models of this kind have been developed by Goodfriend and McCallum [5], for example.

Joseph Stiglitz [6] reexamined the Modigliani-Miller propositions, and found that two assumptions of their model are important for their proof; individuals and firms borrow at the same interest rate, and there is no bankruptcy. He states [6] that, "It should be clear that these assumptions are not independent." However, he did not pursue the possibility that bankruptcy introduces the need for financial intermediaries to provide the service of 
qualifying and monitoring borrowers and their investments. A model that incorporates these elements is provided in this paper.

Considerations of financial leverage make use of the propositions of Modigliani and Miller [2]. MM Propositions I and II are as follows.

- The market value of a firm is independent of its capital structure. The basic proposition was demonstrated assuming no taxation at the firm level, no bankruptcy, and a constant borrowing and lending rate (but also was demonstrated for the case in which the borrowing and lending rate increases with financial leverage in exactly the same rate for all firms and individuals). Alternatively, the average cost of capital is independent of financial leverage. Stiglitz [6] and Sargent [7] provided a more general proof of Proposition I in the absence of bankruptcy.

- The expected rate of return to equity invested in the firm $\left[E\left(R_{e}\right)\right]$ is equal to the expected rate of return in the absence of borrowing $[E(R)]$ plus an amount that is a linear function of the ratio of debt to equity. That function is

$$
\left[E\left(R_{e}\right)\right]=[E(R)]+\left[E(R)-r_{f}\right](D / S),
$$

$r_{f}$ is the risk-free borrowing and lending rate, $D$ is debt, and $\mathrm{S}$ is equity. $E(R)$ is the rate of return to the asset in the absence of borrowing and $\left[E(R)-r_{f}\right]$ is the risk premium for the investment without leverage. The expected rate of return to equity is increased by borrowing if the expected rate of return to the investment without borrowing exceeds the rate of interest on borrowing.

\section{A Real Estate Investment Example}

The central point in this paper is that the value of an investment is not independent of its capital structure because the borrowing rate is greater than the lending rate, especially if the borrowing rate increases with the loanto-value ratio. The reason for this difference in the borrowing and lending rates is fundamental. Much of the lending in an economy is provided by financial institutions that provide the service of financial intermediation; transforming assets that are less desirable into assets that are preferred by the public (i.e., their own liabilities). Financial intermediaries are in the business of borrowing on a short-term basis and making long-term loans (maturity intermediation), risk reduction through diversification, providing low-cost contracts, and facilitating payments. In doing so, they undertake risks-interest rate risk and default risk. Lenders examine the quality of the borrowers and the purposes for which they wish to bor- row, and monitor the performance of the borrower. Other lending is accomplished in the form of bonds issued by firms. Firms use the services provided by financial institutions and bond rating agencies. The difference in the borrowing and lending rates reflects the value of these specialized services.

Consider a modification of the constructive demonstration of homemade leverage used by Modigliani and Miller [2] for MM Proposition I. This example introduces a borrowing rate that is greater than the lending rate, but does not introduce bankruptcy. Both of these elements are included in the model presented in Section 4 below. Suppose an investor owns a property (no borrowing) with value $V_{1}$ that produces expected annual income $Y_{1}=X$, which is net operating income plus capital appreciation over the year. Then suppose that this investor decides to sell this property and purchase a portion of the equity in another property with expected annual income $X$ that is in the same "risk class," and lends the remaining amount of his/her funds to some other investor (e.g., purchases bonds). The investor's return from this alternative investment portfolio is

$$
Y_{2}=\left(e_{2} / E_{2}\right)\left(X-R_{D} D\right)+R_{L} L,
$$

where $e_{2}$ is the investor's equity investment, $E_{2}$ is the total equity in the property, $R_{D}$ and $R_{L}$ are the borrowing and lending rates, $D$ is the amount that was borrowed on the property, and $L$ is the amount lent by the investor. Under what conditions will the investor's income from the new portfolio equal $X$ ? We know that $V_{1}=e_{2}+L$ and $V_{2}=E_{2}+D$.

Modigliani and Miller [2] propose homemade leverage where

$$
e_{2}=\left(E_{2} / V_{2}\right) V_{1} \text { and } L=\left(D / V_{2}\right) V_{1} \text {. }
$$

Substitution of these definitions into Equation (2) produces

$$
Y_{2}=\left(V_{1} / V_{2}\right) X+\left(V_{1} / V_{2}\right) D\left(R_{L}-R_{D}\right) .
$$

The arbitrage condition $Y_{2}=X$ holds if $R_{L}=R_{D}$ and thus $V_{1}=V_{2}$. This is MM Proposition I. However, if the borrowing rate that was used exceeds the lending rate that is available to the investor in question, then $Y_{2}=X$ if

$$
V_{2} / V_{1}=1-(D / X)\left(R_{D}-R_{L}\right)<1 .
$$

If the borrowing rate is greater than the lending rate available to the investor, then the value of the property in the new portfolio must be lower than the property with no borrowing, and the reduction in value depends upon the amount that was borrowed and the difference between the two interest rates. Equation (4) can be rewritten as

$$
V_{2}=V_{1}+[D / E(R)]\left(R_{L}-R_{D}\right) \text {. }
$$

It is well known that the borrowing rate in real estate 
increases with the loan-to-value ratio, so the lending rate can equal the borrowing rate if somehow the investor loans to some other real estate investors who have applied the same degree of leverage as was applied to the property involved in this example. This is an unlikely scenario.

The expected rate of return to equity with a borrowing rate that exceeds the lending rate is

$$
E\left(R_{e}\right)=E(R)+\left[E(R)-r_{f}\right]\left(R_{B} / R_{L}\right)(D / E) .
$$

If the borrowing and lending rates are equal, then Equation (6) reduces to MM Proposition II. The expected rate of return to equity must increase with leverage at a greater rate than in MM Proposition II to compensate for the higher cost of borrowing.

The other side of the Modigliani-Miller demonstration of Proposition I [2] involves investors who borrow on personal account to replicate the leverage of a firm. Consider an investor that owns a portion $\alpha$ of real estate property number 2 . The annual income of the investor is

$$
Y_{2}=\alpha\left(X-R_{B} D_{2}\right),
$$

where $\alpha=e_{2} / E_{2}$ (the share of equity owned by the investor), and $D_{2}$ is the amount of debt that was used in the acquisition the property.

Now suppose that the investor sells his/her share in the investment $s_{2}=\alpha S_{2}$ and borrows amount $\alpha D_{2}$ in order to purchase property number 1 outright. The income from this new investment is

$$
Y_{1}=\left[\alpha\left(S_{2}+D_{2}\right) / S_{1}\right] X-R_{B^{*}} \alpha D_{2} .
$$

Here $R_{B^{*}}$ is the interest rate on the personal loan that is used. As Modigliani and Miller [2] state,

He could do so by utilizing the amount $\alpha S_{2}$ realized from his initial holding and borrowing an additional amount $\alpha D_{2}$ on his own credit, pledging his new holdings in company 1 as a collateral.

By definition $V_{1}=S_{2}+D_{2}$ and $V_{1}=S_{1}$.

However, “... pledging his new holdings in company 1 as collateral” is equivalent to taking out a mortgage loan-as was done to purchase investment number 2 . This means that $R_{B}=R_{B^{*}}$, and the investor has exactly replicated investment number 2 . The investor has sold one investment in order to borrow and make another investment under exactly the same terms - the same borrowing rate schedule and the same amount of leverage. Under these conditions $Y_{1}=Y_{2}$ and $V_{1}=V_{2}$. This demonstration only shows that $V_{2}$ cannot be greater than $V_{1}$ because the two borrowing rates in question are equal. The previous example shows that borrowing reduces property value.

\section{The Market for Investment Property}

Thus far the paper has considered only examples with two properties with identical expected annual incomes. Now consider the market for such properties. The supply of such assets is fixed at a large number, and the market of perfectly competitive. There are many investing firms that vary in their appetite for expected return to equity and risk. Suppose that all of the investing firms are untaxed. Market equilibrium is established by the willingness of the marginal investor to pay for the property. Some untaxed investing entities such as pension funds and some real estate investment trusts borrow little or nothing and have high reservation prices for the property. Other investors borrow a great deal of money because they wish to increase the expected rate of return to equity (or are equity constrained).

Figure 1 displays an example of equilibrium in the market for property in a particular risk class. Supply is fixed at S. The demand for this type of property (by the untaxed investment entities) has a horizontal portion at $V_{D=0}$ for those entities that do not borrow, and then the demand price declines with quantity as entities that borrow are added-in the order of the amount that they choose to borrow. Equilibrium is established at $V^{*}$. The market fixes the maximum amount $D^{*}$ that is borrowed by the successful marginal bidder. This marginal bidder earns a return to equity equal to

$$
E\left(R_{e}\right)=E(R)+\left[E(R)-r_{f}\right]\left(R_{B} / R_{L}\right)(D * / E) .
$$

Market value declines with the amount borrowed by the marginal buyer. The expected rate of return to the investment in the absence of borrowing is $E(R)=X / V^{*}$. The fact that the marginal investor borrows enhances the expected rate of return for the infra-marginal investors.

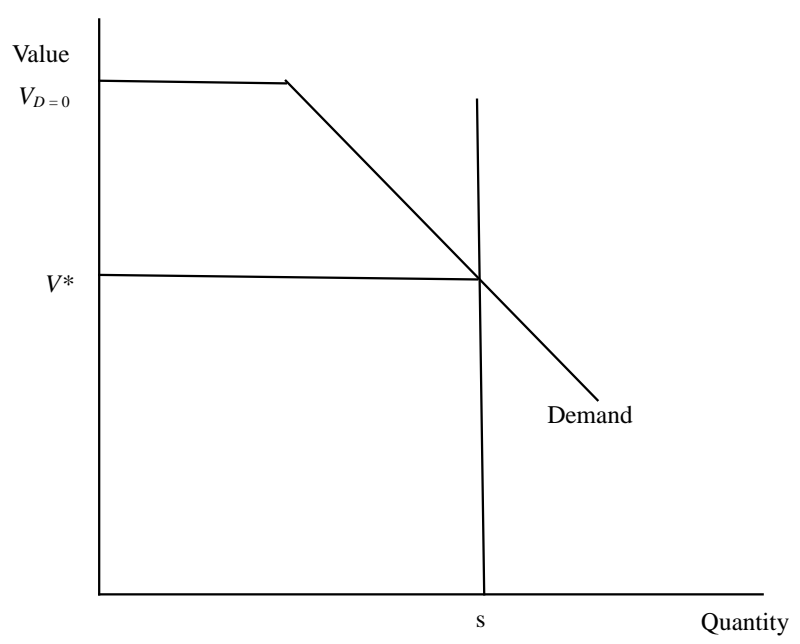

Figure 1. Market for investment property. 


\section{A State-Preference Presentation}

A more formal proof of the basic proposition can be formulated using the state-preference approach adopted by Stiglitz [6] and Sargent [7]. Assume that there is only one date in the "future," and that there are $N$ possible future states of the world. The index of future states of the world is $\theta=1,2, \cdots, N$. An individual has a concave utility function $U$, and utility depends upon the future state of the world and the amount of money $M$ in his/her possession at that time:

$$
U=U[M(\theta)] .
$$

The individual has a set of subjective probabilities over the states of the world $\pi(\pi 2,(t), \cdots(N)$ that sum to 1.0. Individual are assumed to maximize expected utility $V$ :

$$
v=\sum_{\theta} \pi(\theta) U[M(\theta)] .
$$

The individual is assumed to have an endowment of $M^{0}$ at the present that is invested to provide for future consumption.

Consider a competitive economy in which there are $\mathrm{N}$ markets for contingent (Arrow-Debreu) securities, where each one promises to pay one dollar if the corresponding state of the world $\theta$ occurs. The price of a security, $p(\theta)$, is the price of the claim on one dollar should state $\theta$ occur. The units of $p(\theta)$ are dollars in the current period per dollar in state $\theta$ in the future. The price of a certain dollar in the future is $\sum_{\theta} p(\theta)$, which is the reciprocal of one plus the risk-free interest rate. Perfect markets for contingent securities in all states of the world mean that it is possible to insure against any risk.

Now consider firms that produce output that individuals purchase in the future. We assume an absence of taxes. A firm produces a return net of current labor and materials costs that depends upon the state of the world; $X(\theta)$. The firm issues bonds in the amount of B dollars, and promises now to pay $B(1+r-c)$ to its bond holders at the future date, provided that the firm is not bankrupt at that time; i.e., $X(\theta) \geq B(1+r-c)$. The rate at which the firms borrow is $r$, and the rate that it is paid as a lender is $r-c<r$. The firms goes bankrupt if $X(\theta)$ $<B(1+r)$, so the realized returns to bonds depend upon the state of the world as follows:

$$
1+r(\theta)-c\left\{\begin{array}{l}
=1+r-c \text { if } X(\theta) \geq B(1+r) \\
=[X(\theta) / B]-c \text { if } X(\theta)<B(1+r)
\end{array}\right.
$$

The model includes possible bankruptcy so that there is a need for financial intermediation. The amount $c B$ is the cost of providing the financial intermediation services in which it was determined that the firm was in fact eligible to borrow amount $B$. It is assumed that this cost must be paid.

The value of the firm's bonds is equal to the sum of the values of the contingent securities on which the bond consists implicitly. States of the world in which the firm does not go bankrupt are indexed as $\theta(a)$, and states of the world in which the firm goes bankrupt are indexed as $\theta(b)$. The value of the firm's bonds to the lenders is:

$$
\begin{aligned}
B_{L}= & {[1+r(\theta)-c] B \sum_{\theta(a)} p(\theta) } \\
& +B\left\{\sum_{\theta(b)}[X(\theta) / B]-c\right\} p(\theta)
\end{aligned}
$$

The value of the firm's equity is:

$$
E=\sum_{\theta(a)}[X(\theta)-(1+r) B] p(\theta) .
$$

Therefore, the value of the firm $V$ is:

$$
\begin{aligned}
& V=E+B_{L}=\sum_{\theta}[X(\theta)-c B] p(\theta), \text { so } \\
& \partial V / \partial B<0 \text { and } \partial V / \partial c<0
\end{aligned}
$$

The value of the firm decreases with both the amount borrowed and the cost of financial intermediation. If the borrowing and lending rates are equal, then $c=0$ and the value of the firm does not depend upon borrowing. This is, of course, MM Proposition I. Introduction of a corporate income tax on the firm (with deductions for interest payments) generates the conclusion that the cost of financial intermediation tends to be offset by the tax advantages of borrowing.

\section{Conclusion}

This paper has shown that, if the borrowing rate exceeds the lending rate (as in the case of financial intermediation services), then the value of a firm declines with financial leverage. The value of the firm is reduced by the cost of the financial intermediation services. If the borrowing rate and the lending rates are equal, then the value of the firm is independent of financial leverage, as in Modigliani-Miller Proposition I. This proposition holds in the presence of the possibility of firm bankruptcy, but it would seem that the possibility of firm bankruptcy creates the need for financial intermediation, which has real resource costs creating a borrowing rate that exceeds the lending rate.

\section{References}

[1] S. Chan, J. Erickson and K. Wang, "Real Estate Investment Trusts: Structure, Performance, and Investment Opportunities,” Oxford University Press, New York, 2003.

[2] F. Modigliani and M. Miller, "The Cost of Capital, Cor- 
poration Finance, and the Theory of Investment," The American Economic Review, Vol. 48, No. 3, June 1958, pp. 261-297.

[3] K. Arrow, B. Bernheim, M. Feldstein, D. McFadden, J. Poterba and R. Solow, "100 Years of the American Economic Review: The Top 20 Articles,” American Economic Review, Vol. 101, No. 1, 2011, pp. 1-8. doi:10.1257/aer.101.1.1

[4] M. Woodford, "Financial Intermediation and Macroeconomic Analysis," Journal of Economic Perspectives, Vol. 24, No. 4, 2010, 21-44. doi:10.1257/jep.24.4.21
[5] M. Goodfriend and B. McCallum, "Banking and Interest Rates in Monetary Policy Analysis: A Quantitative Exploration,” Journal of Monetary Economics, Vol. 54, No. 5, July 2007, pp. 1480-1507. doi:10.1016/j.jmoneco.2007.06.009

[6] J. Stiglitz, "A Re-examination of the Modigliani-Miller Theorem,” The American Economic Review, Vol. 59, No. 5, December 1969, pp. 784-793.

[7] T. Sargent, “Macroeconomic Theory," 2nd Edition, Academic Press, Orlando, 1987. 